\title{
Konrad Kopystyński
}

Uniwersytet Wrocławski

Tadeusz Kocowski

Opiekun naukowy — Scientific Tutor

DOI: $10.19195 / 1733-5779.23 .5$

\section{Unormowanie przesłanek udzielenia koncesji na prowadzenie kasyna gry a ochrona interesu publicznego}

JEL Classification: $\mathrm{K}, \mathrm{H}$

Słowa kluczowe: gry hazardowe, interes publiczny, koncesja, kasyna gry, wyłączenie

Keywords: gambling, public interest, concession, casino, exclude

\begin{abstract}
Abstrakt: Wyłączenie stosowania negatywnych przesłanek ogólnych przyznania koncesji określonych w ustawie - Prawo przedsiębiorców w sprawach o udzielenie koncesji na prowadzenie kasyna gry nie powoduje ograniczenia ochrony interesu publicznego w porównaniu ze standardem wyznaczonym regulacją ogólną. Przesłanki uzyskania koncesji na prowadzenie kasyna gry określone w ustawie o grach hazardowych nie zostały bowiem unormowane w sposób węższy niż negatywne przesłanki ogólne otrzymania koncesji z ustawy — Prawo przedsiębiorców. Taki wniosek wynika z porównania obydwu regulacji. Co więcej, na gruncie uprzednio obowiązującej ustawy o swobodzie działalności gospodarczej część ogólnych negatywnych przesłanek przyznania koncesji miała szerszy zakres niż przesłanki uzyskania koncesji na prowadzenie kasyna gry. Jednocześnie obowiązywało wówczas wyłączenie stosowania przepisów ogólnych dotyczących przesłanek przyznania koncesji w sprawach o udzielenie koncesji na prowadzenie kasyna gry. Wyeliminowanie na gruncie ustawy - Prawo przedsiębiorców części ogólnych negatywnych przesłanek przyznania koncesji obowiązujących na gruncie uchylonej ustawy o swobodzie działalności gospodarczej spowodowało, że w sprawach o udzielenie koncesji na prowadzenie kasyna gry poziom ochrony interesu publicznego, wyznaczony treścią negatywnych przesłanek ogólnych otrzymania koncesji, przestał odbiegać od poziomu występującego w sprawach o wydanie pozostałych rodzajów koncesji. Rozwiązanie to wyeliminowało pewną niespójność systemową, jaka miała miejsce przed wprowadzeniem ustawy — Prawo przedsiębiorców.
\end{abstract}




\title{
Regulation of premises of granting a concession for operating casino games and the protection of the public interest
}

\begin{abstract}
Exclusion of application general negative premises of granting a concession from the entrepreneurs law in cases of granting a concession for operating casino games does not cause a limitation of protection of the public interest compared to standard which is appointed by general regulation. Premises of granting the concession for operating casino games from the law on gambling do not have a narrower scope than general negative premises of granting a concession from the entrepreneurs law. That conclusion is based on the comparison between the both regulations. Moreover, on the grounds on the previous freedom of economic activity act, a few general negative premises of granting a concession had a wider scope than premises of granting the concession for operating casino games. Simultaneously, exclusion of application general rules in cases of granting the concession for operating casino games also then was in force. Elimination a few general negative premises in the entrepreneurs law, which were applying on base of the repealed freedom of economic activity act, caused that level of the protection of public interest appointed by scope of general negative premises of granting a concession is not lower than level of the protection of public interest in cases of granting a concession for operating casino games. That solution eliminated a certain systemic inconsistency, which had existed before the entrepreneurs law came into force.
\end{abstract}

\section{Wstęp}

Wykonywanie działalności gospodarczej polegającej na prowadzeniu kasyna gry wymaga uprzedniego uzyskania koncesji. Zasadą jest, że przesłanki udzielenia koncesji określone są przepisami ustawy z dnia 6 marca 2018 roku — Prawo przedsiębiorców ${ }^{1}$, a nadto uzupełnione odrębnymi przesłankami uregulowanymi przepisami ustaw szczególnych, normujących konkretny rodzaj koncesjonowanej działalności gospodarczej. Od tej zasady ustawodawca odstąpił w przypadku koncesji na prowadzenie kasyna gry, przyjmując w treści art. 32 ust. 6 ustawy z dnia 19 listopada 2009 roku o grach hazardowych ${ }^{2}$, że w sprawach o udzielenie koncesji na prowadzenie kasyna gry wyłączone jest stosowanie przepisów ustawy - Prawo przedsiębiorców. W konsekwencji przesłanki udzielenia tej koncesji określone w ustawie o grach hazardowych nie tyle uzupełniają, ile zastępują przesłanki ogólne z ustawy — Prawo przedsiębiorców. Porównanie przesłanek zawartych w obydwu ustawach pozwoli ocenić, czy takie rozwiązanie nie naraża na niezasadne uszczuplenie interesu publicznego, którego ochrona w przypadku koncesjonowanych rodzajów działalności gospodarczej tradycyjnie jawi się jako szczególnie istotna.

Następnie zbadane zostanie, w jakim stopniu na ocenę realizacji ochrony interesu publicznego wpłynęło wejście w życie ustawy - Prawo przedsiębiorców w miejsce uchylonej ustawy z dnia 2 lipca 2004 roku o swobodzie działalności

${ }^{1}$ Dz.U. z 2018 r. poz. 646 (dalej: p.p. lub ustawa - Prawo przedsiębiorców).

2 Dz.U. z 2018 r. poz. 165 (dalej: u.g.h. lub ustawa o grach hazardowych). 
gospodarczej ${ }^{3}$. W tym celu przesłanki przyznania koncesji na prowadzenie kasyna gry porównane zostaną z ogólnymi przesłankami udzielenia koncesji obowiązującymi na gruncie uchylonej ustawy o swobodzie działalności gospodarczej. W tym miejscu trzeba zaznaczyć, że także w uprzednio obowiązującym stanie prawnym w sprawach o udzielenie koncesji na prowadzenie kasyna gry wyłączone było stosowanie przepisów ustawy o swobodzie działalności gospodarczej — na mocy art. 32 ust. 6 u.g.h. w ówczesnym brzmieniu.

W niniejszym opracowaniu analizie zostaną poddane przesłanki udzielenia koncesji (warunki, jakie musi spełnić przedsiębiorca ubiegający się o uzyskanie koncesji) oraz przesłanki odmowy udzielenia koncesji (negatywne przesłanki udzielenia koncesji, tj. okoliczności, na podstawie których organ koncesyjny odmawia lub może odmówić udzielenia koncesji). Należy mieć przy tym na uwadze, że tradycyjny podział przesłanek na pozytywne (przesłanki udzielenia koncesji) i negatywne (przesłanki odmowy udzielenia koncesji) ma charakter umowny, a z każdej przesłanki negatywnej można wyprowadzić przesłankę pozytywną i odwrotnie ${ }^{4}$. Ich istota zawiera bowiem zależność tego rodzaju, że zaistnienie okoliczności stanowiącej przesłankę pozytywną jednocześnie można traktować jako niezrealizowanie się przesłanki negatywnej, natomiast wystąpienie okoliczności odpowiadającej w swojej treści przesłance negatywnej każdorazowo oznaczać będzie brak spełnienia przesłanki pozytywnej. Przedstawiając to na przykładzie ustawy o grach hazardowych: jeżeli pozytywną przesłanką przyznania koncesji jest uzyskanie przez przedsiębiorcę ubiegającego się o koncesję pozytywnej opinii rady gminy o lokalizacji kasyna gry, brak takiej pozytywnej opinii w efekcie będzie stanowić przesłankę negatywną przyznania koncesji.

\section{Definicja koncesji}

Nie dysponujemy definicją legalną koncesji. W ślad za orzecznictwem można wskazać jednak, że jest to publicznoprawne uprawnienie podmiotowe, wydawane $\mathrm{w}$ drodze decyzji administracyjnej indywidualnie oznaczonemu podmiotowi spełniającemu ustawowo określone przedmiotowo-podmiotowe warunki wykonywania danego rodzaju działalności gospodarczej ${ }^{5}$. Podkreśla się przy tym, że koncesja jest aktem niezbywalnym ${ }^{6}$ i konstytutywnym ${ }^{7}$. Pośród tradycyjnych reglamentacyjnych środków prawnych koncesję uznaje się za najbardziej restrykcyjny (poza monopolem prawnym). Kwalifikowany charakter koncesji w tym ujęciu wynika z tego, że w założeniu obejmuje ona rodzaje działalności gospodarczej

3 Dz.U. z 2017 r. poz. 2168 (dalej: u.s.d.g. lub ustawa o swobodzie działalności gospodarczej).

4 S. Waltoś, Proces karny. Zarys systemu, Warszawa 2008, s. 459.

5 Por. wyrok SN z dnia 8 maja 1998 roku, III RN 34/98, Legalis nr 42191.

${ }^{6}$ C. Kosikowski, Nowe regulacje prawne w zakresie swobody działalności gospodarczej, PiP 2004, z. 10, s. 5.

7 T. Szanciło, Przedsiębiorca w prawie polskim, PPH 2005, nr 3, s. 36. 
o szczególnym znaczeniu dla państwa i jego kluczowych interesów, w tym kwestii bezpieczeństwa jednostkowego i powszechnego ${ }^{8}$. Dość powiedzieć, że koncesjonowane rodzaje działalności gospodarczej w przeszłości objęte były państwowym monopolem, z którego jednak zrezygnowano wraz z rozwojem stosunków społeczno-gospodarczych ${ }^{9}$. Tło historyczne podkreśla dodatkowo specyfikę sfer aktywności gospodarczej objętych koncesjonowaniem. Wreszcie, definiując koncesję, wskazuje się często na jej uznaniowy charakter ${ }^{10}$. Uznaniowość w odniesieniu do koncesji sprowadzać się będzie z jednej strony do swobody rozstrzygnięcia w sprawie (wobec fakultatywnego charakteru przesłanek, w tym przesłanek udzielenia koncesji), a także w występowaniu w przepisach dotyczących koncesji licznych pojęć niedookreślonych (również w przepisach konstytuujących przesłanki udzielenia koncesji; ty tułem przykładu — wzgląd na bezpieczeństwo państwa).

Obwarowanie obowiązkiem uzyskania koncesji wykonywania działalności gospodarczej w zakresie urządzania niektórych gier hazardowych świadczy jednoznacznie, że dla ustawodawcy jest to branża o wyjątkowym znaczeniu, wymagająca szczególnej regulacji reglamentacyjnej w celu zapewnienia niezbędnej ochrony interesu publicznego. Oceny tej nie zmienia ciekawe spostrzeżenie, że akurat koncesja na prowadzenie kasyna gry nie potwierdza tezy o tym, że wspólną cechą koncesjonowanych działalności było w przeszłości wykonywanie ich w warunkach monopolu państwa ${ }^{11}$.

\section{Rodzaje koncesjonowanych gier hazardowych}

Zgodnie z art. 6 ust. 1 u.g.h. działalność w zakresie gier cylindrycznych, gier w karty, gier w kości i gier na automatach może być prowadzona po uzyskaniu koncesji na kasyno gry, z zastrzeżeniem wyjątków przewidzianych w ustawie (gry na automatach oraz gry w pokera mogą być organizowane również poza kasynami gry, w tym przez Internet). Przytoczony przepis wymienia katalog gier hazardowych podlegających koncesjonowaniu, natomiast kolejne przepisy przytaczają ich definicje. Gry cylindryczne oraz gry w kości należą do gier losowych, a więc gier o wygrane pieniężne lub rzeczowe, których wynik w szczególności zależy od przypadku (art. 2 ust. 1 u.g.h.). Dodatkowo ustawodawca wskazał, że w grach cylindrycznych uczestniczy się przez wytypowanie liczb, znaków lub innych wyróżników, a wysokość wygranej zależy od określonego z góry stosunku wpłaty do wygranej, zaś wynik gry ustalany jest za pomocą urządzenia obrotowego (art. 2

8 T. Kocowski, Reglamentacja działalności gospodarczej w polskim administracyjnym prawie gospodarczym, Wrocław 2009, s. 273.

9 C. Kosikowski, Koncesje w prawie polskim, Kraków 1996, s. 26.

${ }^{10}$ K. Klecha, Wolność działalności gospodarczej w Konstytucji RP, Warszawa 2009, s. 250.

11 M. Zdyb, Komentarz do art. 46 u.s.d.g., [w:] M. Sieradzka, M. Zdyb, Ustawa o swobodzie działalności gospodarczej. Komentarz, Warszawa 2013. 
ust. 1 pkt 4 u.g.h.). Z kolei gry na automatach to gry na urządzeniach mechanicznych, elektromechanicznych lub elektronicznych, w tym komputerowych, o wygrane pieniężne lub rzeczowe, w których gra zawiera element losowości, a także gry na urządzeniach mechanicznych, elektromechanicznych lub elektronicznych, w tym komputerowych, organizowane w celach komercyjnych, w których grający nie ma możliwości uzyskania wygranej pieniężnej lub rzeczowej, ale gra ma charakter losowy (art. 2 ust. 2 pkt 3 i 5 u.g.h.). Natomiast grami w karty są gry black jack, poker i baccarat, jeżeli są rozgrywane o nagrody pieniężne lub rzeczowe (art. 2 ust. 2 pkt 5a u.g.h.).

Oprócz wyżej wskazanych w ustawie o grach hazardowych wymienione są licznie inne rodzaje gier hazardowych, które podlegają mniej ingerencyjnym niż koncesja formom reglamentacji gospodarczej (zezwolenie, dokonanie zgłoszenia). Zastrzeżono przy tym, że działalność w zakresie gier liczbowych, loterii pieniężnych, gry telebingo oraz gier na automatach poza kasynem gry jest objęta monopolem państwa (art. 5 ust. 1 u.g.h.).

\section{Przesłanka uzyskania koncesji jako ograniczenie wolności działalności gospodarczej}

Jak zaznaczono we wstępie, przesłanki uzyskania koncesji na prowadzenie kasyna, uregulowane w ustawie o grach hazardowych, mają charakter wyłączny i nie są uzupełniane przesłankami ogólnymi z ustawy — Prawo przedsiębiorców. Przesądza o tym brzmienie art. 32 ust. 6 u.g.h., zgodnie z którym w sprawach dotyczących udzielenia, odmowy udzielenia, zmiany i cofnięcia koncesji na prowadzenie kasyna gry nie stosuje się przepisów ustawy — Prawo przedsiębiorców. Rozwiązanie to ma charakter wyjątkowy, albowiem w przypadku wszystkich pozostałych koncesjonowanych rodzajów działalności gospodarczej przesłanki zawarte w ustawach szczególnych (dotyczących konkretnych rodzajów działalności gospodarczych) uzupełniają katalog przesłanek ogólnych z ustawy - Prawo przedsiębiorców, a nie go zastępują. Jest to wyraz niezwykłej restrykcyjności, z jaką ustawodawca podszedł do uregulowania zagadnień związanych z prowadzeniem działalności gospodarczej w branży hazardowej. Jedynie na marginesie w tym miejscu należy zaznaczyć, że obowiązująca uprzednio ustawa z dnia 29 lipca 1992 roku o grach i zakładach wzajemnych ${ }^{12} \mathrm{w}$ ogóle nie przewidywała koncesjonowania działalności w zakresie jakichkolwiek gier hazardowych, ograniczając się jedynie do wprowadzenia wymogu w postaci obowiązku uzyskania zezwolenia, a więc aktu reglamentacyjnego o mniej ingerencyjnym charakterze niż koncesja.

W tym miejscu należy zauważyć, że każda dodatkowa przesłanka udzielenia koncesji (negatywna przesłanka uzyskania koncesji) sama przez się ogranicza

12 Dz.U. z 2004 r. Nr 4, poz. 27 z późn. zm. 
uprawnienie przedsiębiorcy do swobodnego wykonywania działalności gospodarczej i stanowi przez to wyjątek od konstytucyjnej zasady wolności gospodarczej ${ }^{13}$. Spostrzeżenie to wpisuje się w ogólną zasadę, w myśl której każdy środek reglamentacyjny nakierowany jest na zwiększenie ochrony interesu publicznego kosztem interesu indywidualnego ${ }^{14}$. W efekcie, wprowadzając dodatkowe przesłanki udzielenia koncesji, ustawodawca zapewnia uzupełniającą ochronę interesu publicznego przy jednoczesnym pogorszeniu sytuacji prawnej przedsiębiorcy. Analogicznie, przy wyłączeniu stosowania określonych przesłanek udzielenia koncesji (lub po prostu uchyleniu przepisów je konstytuujących w ramach procedury legislacyjnej) odpowiednio poszerzona zostaje sfera wolności gospodarczej. Można zatem powiedzieć, że treść wszystkich przesłanek ogólnych udzielenia koncesji wyznacza standard ochrony interesu publicznego w tym zakresie. Należy przy tym zauważyć, że jakiekolwiek ograniczenie wolności działalności gospodarczej dopuszczalne jest wyłącznie przy uwzględnieniu ważnego interesu publicznego, o czym przesądza art. 22 Konstytucji $\mathrm{RP}^{15}$. Wzgląd na ważny interes publiczny stanowi zatem jedną z przesłanek dopuszczalności ograniczenia wolności działalności gospodarczej, w tym ograniczeń w postaci kształtowania kolejnych przesłanek udzielenia koncesji. Mocą art. 32 ust. 6 u.g.h. katalog przesłanek uzyskania koncesji na prowadzenie kasyna gry został zawężony o przesłanki ogólne z ustawy - Prawo przedsiębiorców. Już samo wyłączenie stosowania przesłanek ogólnych świadczy o tym, że ochrona interesu publicznego przez to nie mogła zostać poszerzona (skoro przepis ten eliminuje pewne przesłanki, które same w sobie stanowią ograniczenie zasady wolności gospodarczej przeciwstawianej interesowi publicznemu). Niewykluczone jednak, że interes publiczny nie został uszczuplony w wyniku omawianego wyłączenia z art. 32 ust. 6 u.g.h. Aby tak było, przesłanki ogólne z ustawy Prawo przedsiębiorców musiałyby w całości mieścić się w zakresie treściowym przesłanek uzyskania koncesji na prowadzenie kasyna gry. Innymi słowy, zakres treściowy przesłanek uzyskania koncesji na prowadzenie kasyna gry nie może być węższy od zakresu treściowego przesłanek ogólnych otrzymania koncesji. Porównanie przesłanek z obydwu grup pozwoli rozstrzygnąć tę kwestię.

\section{Przesłanki uzyskania koncesji na prowadzenie kasyna gry na tle regulacji ogólnej z ustawy - Prawo przedsiębiorców}

Żaden przepis ustawy o grach hazardowych nie zawiera katalogu przesłanek uzyskania koncesji na prowadzenie kasyna gry. Przesłanki te rozproszone są

13 Por. wyrok SA w Warszawie z dnia 23 czerwca 2015 roku, sygn. akt VI ACa 1123/14, LEX nr 1814847.

${ }^{14}$ K. Kiczka, [w:] A. Borkowski et al., Administracyjne prawo gospodarcze, Wrocław 2009.

15 Dz.U. Nr 78, poz. 483. 
w wielu odrębnych przepisach ustawy w postaci warunków, jakie musi spełnić przedsiębiorca ubiegający się o uzyskanie wzmiankowanej koncesji. W celu pewnego uproszczenia przesłanki zostaną wymienione z podziałem na dwie grupy: najpierw - pozytywne przesłanki uzyskania koncesji, a następnie przesłanki odmowy udzielenia koncesji. Zaliczenie określonej przesłanki do poszczególnej grupy wynika z redakcji przepisu kształtującego daną przesłankę. I tak, po dokonaniu niezbędnej klasyfikacji, można wymienić następujące pozytywne przesłanki uzyskania koncesji na prowadzenie kasyna gry odnoszące się do przedsiębiorcy ubiegającego się o koncesję:

1) zorganizowanie prawne koncesjonariusza w formie spółki akcyjnej lub spółki z ograniczoną odpowiedzialnością, mającej siedzibę na terytorium Rzeczypospolitej Polskiej, ewentualnie spółki działającej na zasadach właściwych dla tych spółek, mającej siedzibę na terytorium innego państwa członkowskiego Unii Europejskiej lub państwa członkowskiego Europejskiego Stowarzyszenia Wolnego Handlu (EFTA) - strony umowy o Europejskim Obszarze Gospodarczym, pod warunkiem ustanowienia przedstawiciela albo w formie oddziału (art. 6 ust. 5 w zw. z art. 7 a ust. 1 u.g.h.);

2) posiadanie kapitału zakładowego w wysokości nie mniejszej niż 4000000 zł (art. 10 ust. 1 pkt 1 u.g.h.);

3) powołanie rady nadzorczej w spółce $\mathrm{z}$ ograniczoną odpowiedzialnością (art. 10 ust. 4 u.g.h.);

4) wydawanie wyłącznie akcji imiennych w spółce akcyjnej (art. 10 ust. 5 u.g.h.);

5) posiadanie obywatelstwa polskiego lub obywatelstwa państwa członkowskiego Unii Europejskiej, państwa członkowskiego Europejskiego Stowarzyszenia Wolnego Handlu (EFTA) - strony umowy o Europejskim Obszarze Gospodarczym lub Organizacji Współpracy Gospodarczej i Rozwoju przez członków zarządu, rady nadzorczej lub komisji rewizyjnej spółki (art. 11 ust. 1 pkt 2 u.g.h.);

6) posiadanie nienagannej opinii przez wspólników lub akcjonariuszy spółki reprezentujących co najmniej 10\% kapitału zakładowego oraz członków zarządu, rady nadzorczej lub komisji rewizyjnej lub prokurentów, co w szczególności wyklucza skazanie za umyślne przestępstwo lub umyślne przestępstwo skarbowe na terytorium państwa członkowskiego Unii Europejskiej (art. 12 ust. 1 u.g.h.);

7) udokumentowanie legalności źródeł pochodzenia kapitału, niezalegania z zapłatą podatków stanowiących dochód budżetu państwa oraz z zapłatą należności celnych oraz niezalegania z zapłatą składek na ubezpieczenia społeczne oraz na ubezpieczenie zdrowotne, a także zgodność działania spółki z właściwymi przepisami regulującymi przeciwdziałanie praniu pieniędzy oraz finansowaniu terroryzmu, oraz dotyczącymi prowadzenia rachunkowości (art. 34 ust. 1 u.g.h.);

8) uzyskanie pozytywnej opinii rady gminy o lokalizacji kasyna gry (art. 35 pkt 15 u.g.h.). 
Z kolei do negatywnych przesłanek przyznania koncesji na prowadzenie kasyna gry zaliczymy:

1) występowanie w spółce udziałów lub akcji uprzywilejowanych (art. 10 ust. 2 u.g.h.);

2) uzasadnione zastrzeżenia z punktu widzenia bezpieczeństwa państwa, porządku publicznego, bezpieczeństwa interesów ekonomicznych państwa, a także przestrzegania przepisów regulujących przeciwdziałanie praniu pieniędzy oraz finansowaniu terroryzmu w stosunku do spółki lub jej akcjonariuszy (wspólników) posiadających akcje (udziały), których wartość przekracza 10\% kapitału zakładowego spółki, lub członków zarządu, rady nadzorczej, komisji rewizyjnej lub prokurentów (art. 11 ust. 1 pkt 1 u.g.h.);

3) toczenie się postępowania w sprawach o przestępstwa związane z praniem pieniędzy oraz finansowaniem terroryzmu przeciwko akcjonariuszom (wspólnikom) posiadającym akcje (udziały), których wartość przekracza 10\% kapitału zakładowego spółki, lub członkom zarządu, rady nadzorczej, komisji rewizyjnej lub prokurentom (art. 11 ust. 1 pkt 3 u.g.h.);

4) cofnięcie koncesji lub zezwolenia z powodu rażącego naruszenia warunków określonych w koncesji, zezwoleniu lub regulaminie, lub innych określonych przepisami prawa warunków wykonywania działalności, na którą udzielono koncesji lub zezwolenia w terminie 6 lat przed datą złożenia wniosku o koncesję (art. 11 ust. 1 pkt 4 u.g.h.);

5) okoliczność, że akcjonariusze (wspólnicy) posiadający akcje (udziały), których wartość przekracza 10\% kapitału zakładowego spółki, lub członkowie zarządu, rady nadzorczej, komisji rewizyjnej lub prokurenci pełnili te funkcje w spółce, której w terminie 6 lat przed datą złożenia wniosku o koncesję cofnięto koncesję lub zezwolenie z powodu rażącego naruszenia warunków określonych w koncesji, zezwoleniu lub regulaminie, lub innych określonych przepisami prawa warunków wykonywania działalności, na którą udzielono koncesji lub zezwolenia (art. 11 ust. 1 pkt 5 i 6 u.g.h.);

6) wystąpienie limitów dotyczących liczebności mieszkańców na obszarze, na którym zgodnie z wnioskiem miałoby być prowadzone kasyno gry (mogą one być lokalizowane w miejscowościach liczących do 250 tysięcy mieszkańców 1 kasyno, przy czym na każde kolejne rozpoczęte 250 tysięcy mieszkańców liczbę dozwolonych kasyn gry zwiększa się o 1, natomiast łączna liczba kasyn gry w województwie nie może być jednak wyższa niż 1 kasyno na każde pełne 650 tysięscy mieszkańców województwa — art. 15 ust. 1 u.g.h.).

Ustawa - Prawo przedsiębiorców wymienia natomiast następujące negatywne przesłanki przyznania koncesji (przy czym cały czas trzeba mieć na uwadze, że stosownie do treści art. 32 ust. 6 u.g.h. wskazane okoliczności nie będą miały zastosowania do koncesji na prowadzenie kasyna gry): 
1) niespełnienie przez przedsiębiorcę warunków udzielenia koncesji (art. 39 ust. 1 pkt 1 p.p.);

2) zagrożenie obronności lub bezpieczeństwa państwa lub obywateli (art. 39 ust. 1 pkt 2 p.p.);

3) udzielenie koncesji innemu przedsiębiorcy lub przedsiębiorcom w wyniku przeprowadzonej rozprawy albo przetargu (art. 39 ust. 1 pkt 3 p.p.);

4) wydanie decyzji o stwierdzeniu niedopuszczalności wykonywania praw z udziałów albo akcji przedsiębiorcy, na podstawie przepisów ustawy z dnia 24 lipca 2015 roku o kontroli niektórych inwestycji ${ }^{16}$, jeżeli jest to $\mathrm{w}$ interesie publicznym (art. 39 ust. 1 pkt 4 p.p.);

5) wystąpienie przypadków określonych w odrębnych przepisach (art. 39 ust. 1 pkt 5 p.p.).

W pierwszej kolejności należy zauważyć, że wszystkie warunki przyznania koncesji określone w ustawie o grach hazardowych mają charakter obligatoryjny, natomiast redakcja art. 39 ust. 1 p.p. zawierającego zestawienie negatywnych przesłanek przyznania koncesji sugeruje, że są to przesłanki fakultatywne. Wymaga jednak podkreślenia, że w tej sytuacji jest to rozbieżność jedynie pozorna. Jak bowiem wskazuje się w doktrynie, pomimo użycia przez ustawodawcę sformułowania „może odmówić udzielenia koncesji”, w rzeczywistości organ koncesyjny jest związany swoim ustaleniem co do zaistnienia okoliczności wymienionej we wzmiankowanym unormowaniu i powinien wówczas wydać decyzję negatywną, nie ma wszakże w tej sferze miejsca na swobodną decyzję ${ }^{17}$.

Przesłanki wymienione w treści art. 39 ust. 1 pkt 1 i 4 p.p. zawierają klasyczne odesłania: do przepisów ustaw szczególnych normujących dany rodzaj koncesjonowanej działalności gospodarczej, ewentualnie do szczególnych warunków określonych na podstawie tych przepisów przez organ koncesyjny. Odnośnie do pierwszej z wymienionych przesłanek należy wskazać, że szczegółowy zakres i warunki wykonywania działalności gospodarczej podlegającej koncesjonowaniu, w szczególności zasady oraz tryb udzielania, zmiany, zawieszenia, cofnięcia albo ograniczenia zakresu koncesji, określają odrębne przepisy (art. 37 ust. 3 p.p.), a szczegółową informację o wszelkich warunkach uzyskania koncesji organ koncesyjny zamieszcza w Biuletynie Informacji Publicznej (art. 38 p.p.). Z kolei odesłanie ujęte w treści art. 39 ust. 1 pkt 5 p.p. wprost wskazuje, iż ustawodawca uczynił zasadą, że przesłanki określone w przepisach szczególnych mają charakter uzupełniający, a nie zastępujący regulację z ustawy — Prawo przedsiębiorców, co jednak zostało przełamane $\mathrm{w}$ stosunku do koncesji na prowadzenie kasyna gry wobec jednoznacznego brzmienia art. 32 ust. 6 u.g.h.

16 Dz.U. z 2017 r. poz. 1857.

17 S. Koroluk, [w:] Ustawa o swobodzie działalności gospodarczej. Komentarz, red. A. Powałowski, Warszawa 2009, s. 235. 
Przesłanka z art. 39 ust. 1 pkt 3 p.p. nawiązuje do sytuacji, w której o uzyskanie koncesji ubiega się większa liczba przedsiębiorców, niż pozostaje samych koncesji do rozdysponowania. Ustawa o grach hazardowych wprost nie wymienia analogicznej przesłanki odmowy wydania koncesji, jednakże przewiduje ona tryb przetargowy wyboru koncesjonariusza. Zgodnie z treścią art. 33 ust. 2 u.g.h. przetarg ogłasza się i przeprowadza, jeśli o koncesję ubiega się więcej niż jeden podmiot spełniający warunki określone w ustawie. W związku z tym za oczywiste należy uznać, że wybór w postępowaniu przetargowym ofert innych podmiotów wiąże się z odmową udzielenia koncesji wobec podmiotu, którego oferta nie została wybrana. Jest to tym istotniejsze, że ustawodawca przyjął restrykcyjne ograniczenia co do ilości kasyn gry stanowiących przedmiot koncesji. W myśl art. 15 ust. 1 u.g.h. kasyna gry mogą być lokalizowane w miejscowościach liczących do 250 tysięcy mieszkańców - 1 kasyno. Na każde kolejne rozpoczęte 250 tysięcy mieszkańców liczbę dozwolonych kasyn gry zwiększa się o 1. Łączna liczba kasyn gry w województwie nie może być jednak wyższa niż 1 kasyno na każde pełne 650 tysięcy mieszkańców województwa. Wynika z tego, że w praktyce, w związku ze znacznymi obostrzeniami ilościowymi co do wydawanych koncesji, tryb przetargowy stanowi regułę rozstrzygania sprawy o udzielenie koncesji na prowadzenie kasyna gry. W konsekwencji, przeprowadzenie rozprawy administracyjnej w sprawie o udzielenie koncesji na prowadzenie kasyna gry należeć będzie do rzadkości. Wobec obligatoryjnego charakteru unormowania $\mathrm{z}$ art. 33 ust. 2 u.g.h. będzie to bowiem możliwe jedynie w sytuacji, w której o koncesję ubiega się tylko jeden podmiot spełniający warunki określone w ustawie.

Warto w tym miejscu odnotować, że analogiczna przesłanka na gruncie uchylonej ustawy o swobodzie działalności gospodarczej obejmowała swoim zakresem jedynie tryb przetargowy, z pominięciem rozprawy administracyjnej (art. 56 ust. 1 pkt 3 u.s.d.g.). Unormowanie to należało rozpatrywać łącznie z dyspozycją art. 52 ust. 1 u.s.d.g., stosownie do którego jeżeli liczba przedsiębiorców, spełniających warunki do udzielenia koncesji i dających rękojmię prawidłowego wykonywania działalności objętej koncesją, jest większa niż liczba koncesji przewidzianych do udzielenia, organ koncesyjny zarządza przetarg, którego przedmiotem jest udzielenie koncesji. Obecnie obowiązująca ustawa - Prawo przedsiębiorców nie zawiera przepisów obligujących organ koncesyjny do zarządzenia przetargu, odsyłając w tym zakresie do treści ustaw szczególnych. Analizowana zmiana nie przekłada się jednak negatywnie na kwestę zabezpieczenia interesu publicznego w sprawach o udzielenie koncesji na prowadzenie kasyna gry, gdyż przepisy u.g.h. określają warunki zarządzenia obligatoryjnego przetargu, sam zaś tryb przetargowy (wobec daleko posuniętych ograniczeń ilościowych w odniesieniu do koncesji na prowadzenie kasyna gry) pozostaje standardowym trybem przy wyłanianiu koncesjonariusza. 
Ciekawie rzecz wygląda w odniesieniu do przesłanki dotyczącej zagrożenia obronności lub bezpieczeństwa państwa albo obywateli (art. 39 ust. 1 pkt 2 p.p.). Znajduje ona pewne odzwierciedlenie w treści art. 11 ust. 1 pkt 1 u.g.h., który traktuje o uzasadnionych zastrzeżeniach z punktu widzenia bezpieczeństwa państwa, porządku publicznego, bezpieczeństwa interesów ekonomicznych państwa, a także przestrzegania przepisów regulujących przeciwdziałanie praniu pieniędzy oraz finansowaniu terroryzmu w stosunku do spółki koncesjonariusza lub podmiotów pełniących w niej funkcje właścicielskie, zarządzające lub kontrolne. Względy obronności lub bezpieczeństwa państwa albo obywateli stanowią klasyczną klauzulę generalną ${ }^{18}$, podobnie jak wartości wymienione w art. 11 ust. 1 pkt 1 u.g.h. Zawierają one pewne odesłania do elementów typowo pozaprawnych, niezbędnych do właściwej interpretacji przepisów w procesie stosowania prawa przy rozstrzygnięciu konkretnej sprawy. Klauzule generalne często są wykorzystywane przez ustawodawcę, gdy nie można konkretnie i jednoznacznie wskazać pożądanego rozstrzygnięcia, a jednocześnie niezbędne jest należyte zagwarantowanie ochrony interesów publicznych ${ }^{19}$.

Jakkolwiek niemożliwe jest przedstawienie precyzyjnych definicji pojęć w postaci klauzul generalnych $\mathrm{z}$ art. 39 ust. 1 pkt 2 p.p. z uwagi na ich charakter, wskazać można ogólnie, że obronność państwa odnosi się do ,jego zdolności militarnej do przeciwstawienia się agresji zarówno ze strony innych państw, jak i ewentualnych sił wewnętrznych" ${ }^{20}$. Natomiast bezpieczeństwo państwa oznacza „stan braku zagrożeń, umożliwiający państwu (narodowi) bezpieczną egzystencję i rozwój”" ${ }^{21}$. Z kolei zagrożenie bezpieczeństwa obywateli sprowadza się do ,sytuacji, w której powstaje realne zagrożenie dla podstawowych wartości jednostek, jakimi są ich życie i zdrowie" 22 .

Przy porównaniu wartości wymienionych w obydwu przesłankach zwraca uwagę pominięcie przez ustawodawcę bezpieczeństwa obywateli przy regulacji przesłanki negatywnej przyznania koncesji na prowadzenie kasyna gry. Ma ono jednak charakter pozorny, w zamian wykorzystano bowiem pojęcie porządku publicznego, który obejmuje swoim zakresem m.in. ochronę interesu jednostek, w tym ich życia, zdrowia oraz mienia ${ }^{23}$. Nadto, ustawodawca wprowadził dodatkowo w art. 11 ust. 1 pkt 1 u.g.h. pojęcie bezpieczeństwa interesów ekonomicz-

18 M. Sieradzka, [w:] M. Sieradzka, M. Zdyb, op. cit.

19 C. Kosikowski, Ustawa o swobodzie działalności gospodarczej. Komentarz, wyd. 7, LEX 2013, komentarz do art. 56.

${ }^{20}$ K. Kohutek, Komentarz do art. 56 u.s.d.g., [w:] M. Brożyna et al., Swoboda działalności gospodarczej. Komentarz, LEX/El. 2005.

21 W. Wołpiuk, Siły zbrojne w regulacjach Konstytucji RP, Warszawa 1998, s. 47.

22 K. Kohutek, op. cit.

23 B. Banaszak, Konstytucja Rzeczypospolitej Polskiej. Komentarz, komentarz do art. 31, Legalis 2012. 
nych państwa, choć wydaje się, że wchodzi ono w szerszy zakres semantyczny pojęcia bezpieczeństwa państwa. Być może ten zabieg legislacyjny miał na celu podkreślenie roli bezpieczeństwa ekonomicznego państwa w ramach szeroko pojmowanego bezpieczeństwa państwa, co może stanowić pewną wskazówkę dla właściwych organów w zakresie wykładni na etapie stosowania prawa, gdzie aktualizuje się konieczność właściwej interpretacji klauzul generalnych. Podobne spostrzeżenie nasuwa się w odniesieniu do zagadnień dotyczących przeciwdziałania prania pieniędzy oraz finansowania terroryzmu. Katalog wartości, które winny być brane pod uwagę przez organ koncesyjny przy rozpatrywaniu wniosku o udzielenie koncesji pod kątem zaistnienia podstawy do wydania decyzji negatywnej, jest zatem bardzo zbliżony w reżimie ustawy o grach hazardowych oraz ustawy - Prawo przedsiębiorców. Trzeba mieć przy tym na uwadze, że wzmiankowane wartości przypisane są przy koncesji na prowadzenie kasyna gry nie tylko samemu potencjalnemu koncesjonariuszowi w postaci spółki kapitałowej, lecz także określonym podmiotom (wykonującym funkcje właścicielskie, zarządzające lub kontrolne). Katalog tych podmiotów jest dość rozbudowany, dzięki czemu dyspozycja analizowanego przepisu zakrojona jest stosunkowo szeroko. W rezultacie wyłączenie stosowania w sprawach o udzielenie koncesji na prowadzenie kasyna gry przesłanki z art. 39 ust. 1 pkt 2 p.p. nie pociąga za sobą skutku w postaci zubożenia ochrony interesu publicznego. Zakres treściowy przesłanki z art. 11 ust. 1 pkt 1 u.g.h. bowiem co najmniej jej odpowiada, a praktycznie każdą okoliczność faktyczną dotyczącą zagrożenia obronności państwa lub jego bezpieczeństwa albo bezpieczeństwa obywateli można również zakwalifikować w oparciu o wskazane unormowanie $\mathrm{z}$ ustawy o grach hazardowych.

\section{Przesłanki uzyskania koncesji na prowadzenie kasyna gry na tle regulacji ogólnej $z$ uchylonej ustawy o swobodzie działalności gospodarczej}

Katalog negatywnych przesłanek przyznania koncesji ujętych w treści art. 39 ust. 1 p.p. stanowi odwzorowanie analogicznej regulacji zawartej w art. 56 ust. 1 uchylonej u.s.d.g. Choć obydwa unormowania prima facie przedstawiają się podobnie, a dokonane zmiany wydają się mieć jedynie kosmetyczny charakter, po dokładniejszej analizie można dostrzec pewne istotne różnice w ukształtowaniu negatywnych przesłanek udzielenia koncesji. Przede wszystkim trzeba zwrócić uwagę, że na gruncie u.s.d.g. występowały negatywne przesłanki przyznania koncesji umiejscowione poza zestawieniem $\mathrm{z}$ art. 56 ust. 1, a mianowicie:

1) cofnięcie koncesji z powodu wydania prawomocnego orzeczenia zakazującego przedsiębiorcy wykonywania działalności gospodarczej objętej koncesją lub naruszenia warunków określonych w koncesji lub innych warunków wyko- 
nywania koncesjonowanej działalności gospodarczej w terminie 3 lat przed datą złożenia wniosku o ponowne udzielenie koncesji w takim samym zakresie (art. 61 u.s.d.g.);

2) brak dawania rękojmi prawidłowego wykonywania działalności objętej koncesją w przypadku, gdy liczba przedsiębiorców ubiegających się o uzyskanie koncesji i spełniających warunki do jej udzielenia jest większa niż liczba koncesji przewidzianych do udzielenia (art. 52 ust. 1 u.s.d.g.).

Analogiczne przesłanki nie ostały się natomiast na gruncie obecnie obowiązującej ustawy — Prawo przedsiębiorców.

W pierwszej kolejności omówiona zostanie kwestia rękojmi prawidłowego wykonywania działalności gospodarczej objętej koncesją. Występują wątpliwości co do tego, czy brak dawania rękojmi na gruncie obowiązywania u.s.d.g. należało uznawać za samodzielną negatywną przesłankę przyznania koncesji. Linia orzecznicza w tej kwestii nie była jednolita ${ }^{24}$. Okoliczność ta nie została bowiem ujęta w katalogu z art. 56 ust. 1 u.s.d.g., nadto żaden inny przepis wzmiankowanej ustawy nie stanowił wprost, że przedsiębiorca zainteresowany uzyskaniem koncesji musiał dawać rękojmię prawidłowego wykonywania koncesjonowanej działalności. Nie wdając się w tym miejscu w szczegóły, należy zauważyć, że już bezspornie na gruncie art. 52 ust. 1 u.s.d.g. rękojmia prawidłowego wykonywania działalności gospodarczej była okolicznością relewantną prawnie przy postępowaniu przetargowym. Zgodnie z przywołanym przepisem, jeżeli liczba przedsiębiorców spełniających warunki do udzielenia koncesji i dających rękojmię prawidłowego wykonywania działalności objętej koncesją jest większa niż liczba koncesji przewidzianych do udzielenia, organ koncesyjny zarządza przetarg, którego przedmiotem jest udzielenie koncesji. Wynikało z tego, iż brak dawania rękojmi przed danego przedsiębiorcę w sytuacji uzasadniającej zarządzenie obligatoryjnego przetargu skutkował niedopuszczeniem go do postępowania przetargowego. Uzasadnia to wniosek, że brak dawania rękojmi stanowił negatywną przesłankę udzielenia koncesji o charakterze względnym, aktualizowała się ona bowiem jedynie w określonej sytuacji procesowej25.

Jest to spostrzeżenie o tyle istotne, że przecież na gruncie art. 15 ust. 1 u.g.h. liczba koncesji na prowadzenie kasyna gry jest bardzo ograniczona. Obowiązujące obostrzenia ilościowe uzasadniają zatem przyjęcie poglądu, zgodnie z którym w odniesieniu do koncesji na prowadzenie kasyna gry regułą będzie sytuacja,

24 Odnośnie do dopuszczalności uznania braku rękojmi jako samodzielnej przesłanki negatywnej por. wyrok SA w Warszawie z dnia 12 grudnia 2007 roku, sygn. akt VI ACa 1019/07, LEX nr 1645903; postanowienie SN z dnia 4 lipca 2012 roku, sygn. akt III SK 1/12, LEX nr 1238105; stanowisko odmienne wyrok SN z dnia 9 lutego 2017 roku, sygn. akt III SK 71/15, LEX nr 2254781; wyrok WSA w Warszawie z dnia 20 maja 2015 roku, sygn. akt VI SA/Wa 3504/14, LEX nr 2086071.

${ }^{25}$ K. Kohutek, Komentarz do art. 50 u.s.d.g., [w:] M. Brożyna et al., op. cit., a także wyrok SA w Warszawie z dnia 23 czerwca 2015 roku, sygn. akt VI ACa 1123/14, LEX nr 1814847. 
w której liczba przedsiębiorców spełniających warunki do uzyskania koncesji jest większa niż liczba koncesji do rozdysponowania.

Samo pojęcie rękojmi prawidłowego wykonywania działalności gospodarczej objętej koncesją nie miało na gruncie u.s.d.g. legalnej definicji. Było to kolejne występujące na gruncie tej ustawy pojęcie niedookreślone ${ }^{26}$. Można jednak przyjąć, iż rękojmię dawał ten przedsiębiorca, co do którego można było oczekiwać, że będzie on należycie wykonywał koncesjonowaną działalność. Warto przy tym zauważyć, że ocena dawania przez niego rękojmi kształtowana była na podstawie dotychczasowej wiedzy na temat danego przedsiębiorcy, natomiast samo wyobrażenie o sposobie wykonywania działalności odnosiło się już do sytuacji przyszłej, tj. okresu po uzyskaniu koncesji ${ }^{27}$.

Podkreślenia wymaga, że w ustawie o grach hazardowych w żadnym fragmencie nie znajdujemy bezpośredniego nawiązania do rękojmi prawidłowego wykonywania działalności gospodarczej. Ustawodawca w ogóle nie używa w treści ustawy tego pojęcia. Do rękojmi nawiązują w pewnym stopniu inne warunki odnoszące się do potencjalnego koncesjonariusza, a określone w ustawie o grach hazardowych, w tym wymóg posiadania nienagannej opinii przez podmioty spełniające funkcje właścicielskie, zarządzające i kontrolne w spółce (art. 12 ust. 1 u.g.h.) czy też zakaz toczenia się postępowania $\mathrm{w}$ sprawach o przestępstwa związane $\mathrm{z}$ praniem pieniędzy oraz finansowaniem terroryzmu w stosunku do takich osób (art. 11 ust. 1 pkt 3 u.g.h), wymóg dotyczący udokumentowania wiarygodności sytuacji finansowej przedsiębiorcy (art. 34 ust. 1 u.g.h.) czy wreszcie określona na wysokim poziomie dolna granica kwotowa kapitału zakładowego spółki (art. 10 ust. 1 pkt 1 u.g.h.). Niewątpliwie wymienione okoliczności wpływają na ocenę tego, czy dany przedsiębiorca daje rękojmię prawidłowego wykonywania działalności gospodarczej objętej koncesją, jednakże nie wyczerpują tego pojęcia. W konkretnym stanie prawno-faktycznym również inne okoliczności mogą mieć w tym przedmiocie duże znaczenie, stąd do zaniechania wykorzystania przez ustawodawcę pojęcia niedookreślonego w postaci rękojmi prawidłowego wykonywania koncesjonowanej działalności przy regulacji przesłanek przyznania koncesji na prowadzenie kasyna gry należało odnieść się krytycznie. Był to bowiem kolejny przykład, w którym wyłączenie z art. 32 ust. 6 u.g.h. rodziło skutek w postaci rzeczywistego pomniejszenia ochrony interesu publicznego. $\mathrm{Na}$ gruncie ustawy - Prawo przedsiębiorców ustawodawca całkowicie zrezygnował z unormowania kwestii rękojmi prawidłowego wyko-

26 Wyrok WSA w Warszawie z dnia 5 sierpnia 2010 roku, sygn. akt VI SA/Wa 1212/10, LEX nr 737911; a także C. Kosikowski, Ustawa o swobodzie działalności..., komentarz do art. 50.

27 A. Powałowski, [w:] Ustawa o swobodzie działalności gospodarczej. Komentarz, red. A. Powałowski, Warszawa 2009, s. 225. 
nywania działalności gospodarczej, a tym samym obniżył ogólny standard ochrony interesu publicznego na rzecz poszerzenia wolności prowadzenia działalności gospodarczej w tym zakresie. Tym samym wyeliminowany został stan rzeczy, w którym w sprawach o udzielenie koncesji na prowadzenie kasyna gry poziom ochrony interesu publicznego był w nieuzasadniony sposób pomniejszony w porównaniu ze standardem wynikającym z regulacji ogólnej, a znajdującym zastosowanie w sprawach o udzielenie każdego innego rodzaju koncesji.

Przechodząc do analizy negatywnej przesłanki przyznania koncesji z art. 61 u.s.d.g., należy podkreślić jej temporalny charakter ${ }^{28}$. Podobną przesłankę temporalną zawiera dyspozycja art. 11 ust. 1 pkt 4-6 u.g.h., jednak odmiennie unormowaną. Negatywna przesłanka przyznania koncesji na prowadzenie kasyna gry z jednej strony określa dłuższy termin (6 lat od dnia wydania decyzji o cofnięciu koncesji do dnia ponownego złożenia wniosku wobec 3 lat w myśl regulacji ogólnej), z drugiej zaś posiada węższą dyspozycję w odniesieniu do powodu cofnięcia koncesji. Obejmuje bowiem jedynie rażące naruszenie warunków wykonywania koncesjonowanej działalności, natomiast w drugim przypadku może to być również „lżejsze” naruszenie, niemające charakteru „rażącego”. Nadto, w reżimie u.s.d.g. jako osobny możliwy powód wskazane zostało wydanie prawomocnego orzeczenia zakazującego przedsiębiorcy wykonywania działalności gospodarczej objętej koncesją. Negatywna przesłanka z ustawy o grach hazardowych nie obejmuje tego przypadku. Z drugiej strony, inna przesłanka z tej ustawy odnosi się do karalności za przestępstwo umyślne (art. 12 ust. 1 u.g.h.), co może się wiązać z orzeczeniem zakazu prowadzenia działalności gospodarczej. W tym miejscu wymaga wyjaśnienia, że ,rażącym” naruszeniem warunków wykonywania koncesji nazwiemy takie naruszenie, które jest oczywiste i dotyczy przepisu wyraźnego i niebudzącego wątpliwości interpretacyjnych ${ }^{29}$. Jednocześnie winno to być naruszenie o wysokim ciężarze gatunkowym, niezależnie od jego oczywistości i łatwości w stwierdzeniu ${ }^{30}$. Takie naruszenie, kwalifikowane jakościowo jako „rażące”, mieści się w dyspozycji obydwu analizowanych przesłanek, ale już naruszenie, któremu nie można przypisać charakteru „rażącego”, a które było powodem wcześniejszego cofnięcia koncesji, może stanowić podstawę odmowy wydania koncesji tylko w oparciu o art. 61 u.s.d.g. Decyzja o cofnięciu koncesji powinna być przy tym wydana w terminie 3 lat od dnia złożenia wniosku o po-

\footnotetext{
${ }^{28} \mathrm{Na}$ temat tymczasowego charakteru przesłanki zob. K. Kohutek, Komentarz do art. 56 u.s.d.g.

29 Por. uzasadnienie uchwały 7 sędziów NSA z dnia 21 kwietnia 2008 roku, sygn. akt I OPS 2/08, LEX nr 364567.

30 Wyrok NSA z dnia 17 września 1997 roku, III SA 1425/96, LEX nr 32626.
} 
nowne przyznanie koncesji, a nie w terminie 6 lat. Warto zatem dostrzec, iż zakresy dyspozycji obydwu negatywnych przesłanek krzyżowały się. W pewnych stanach faktycznych mogły aktualizować się one jednocześnie w stosunku do danego przedsiębiorcy, w innych żadna z przesłanek nie znalazła zastosowania, a w jeszcze innych spełniona została albo tylko pierwsza, albo tylko druga z nich. W takiej sytuacji ustalenie, która z przesłanek korzystniej wpływa na sytuację prawną przedsiębiorcy, możliwe jest wyłącznie poprzez badanie istotnych okoliczności a casu ad casum. Nie zmienia to jednak faktu, że wyłączenie z art. 32 ust. 6 u.g.h. w istocie eliminowało spośród okoliczności mogących stanowić podstawę decyzji odmownej w przedmiocie przyznania koncesji na prowadzenie kasyna gry takie sytuacje, które wykraczają poza dyspozycję analizowanych przesłanek z ustawy o grach hazardowych, a były ujęte w zakresie treściowym art. 61 u.s.d.g. W konsekwencji należało to wiązać z pewnym uszczupleniem ochrony interesu publicznego, w zamian zapewniającym szersze gwarancje przedsiębiorcy w zakresie poszanowania jego wolności do swobodnego prowadzenia działalności gospodarczej. Przepisy ustawy - Prawo przedsiębiorców w ogóle nie normują analogicznej przesłanki temporalnej, jaka występowała na gruncie u.s.d.g. W efekcie, podobnie jak w przypadku przesłanki dotyczącej rękojmi prawidłowego wykonywania działalności gospodarczej, poziom ochrony interesu publicznego w sprawach o udzielenie koncesji na prowadzenie kasyna gry przestał odbiegać od poziomu występującego w sprawach o udzielenie innych koncesji w zakresie wyznaczonym regulacją ogólną.

\section{Wnioski}

Porównanie ogólnych negatywnych przesłanek otrzymania koncesji z ustawy - Prawo przedsiębiorców z przesłankami uzyskania koncesji na prowadzenie kasyna gry określonych w ustawie o grach hazardowych prowadzi do wniosku, że zakres treściowy tych drugich nie jest węższy. W szczególności odnosi się to do treści materialnej przesłanki ogólnej dotyczącej zagrożenia obronności lub bezpieczeństwa państwa albo obywateli, która $\mathrm{w}$ istocie ma pełne pokrycie $\mathrm{w}$ treści analogicznej przesłanki zawartej w ustawie o grach hazardowych. Niezależnie od tego przepisy u.g.h. zawierają oczywiście wiele dodatkowych przesłanek szczególnych, wykraczających treściowo poza przesłanki z regulacji ogólnej, co samo przez się skutkuje poszerzeniem ochrony interesu publicznego w zakresie wyznaczonym dyspozycją przepisów normujących te przesłanki. W rezultacie wyłączenie stosowania przesłanek ogólnych przyznania koncesji do spraw o udzielenie koncesji na prowadzenie kasyna gry nie powoduje nieuzasadnionego pomniej- 
szenia ochrony interesu publicznego w porównaniu ze standardem zakreślonym treścią regulacji ogólnej.

Niemniej, nie można tracić z pola widzenia, że również na gruncie obowiązywania uchylonej ustawy o swobodzie działalności gospodarczej przesłanki przyznania koncesji określone w ustawie o grach hazardowych nie uzupełniały, a zastępowały przesłanki ogólne. Przepisy u.s.d.g. normowały dodatkowe negatywne przesłanki ogólne udzielenia koncesji w porównaniu z obecnie obowiązującą ustawą - Prawo przedsiębiorców. Co więcej, te dodatkowe przesłanki nie znajdowały pełnego pokrycia w treści przesłanek przyznania koncesji na prowadzenie kasyna gry, uregulowanych w ustawie o grach hazardowych. Tytułem przykładu można wymienić w tym miejscu okoliczność dawania rękojmi prawidłowego wykonywania działalności gospodarczej, która miała istotne znaczenie w ramach trybu przetargowego przyznania koncesji uregulowanego ustawą o swobodzie działalności gospodarczej, a która to rękojmia jest pojęciem irrelewantnym prawnie w sprawie o przyznanie koncesji na prowadzenie kasyna gry. Podobny wniosek nasuwa się przy porównaniu przesłanek o charakterze temporalnym, zawartych zarówno w przepisach u.s.d.g., jak i u.g.h. Na skutek wyłączenia stosowania przepisów u.s.d.g. organ koncesyjny w sprawie o udzielenie koncesji na prowadzenie kasyna gry nie mógł wydać decyzji odmownej w oparciu o okoliczność, która na gruncie przepisów ogólnych z u.s.d.g. stanowiła negatywną przesłankę przyznania koncesji. Rozwiązanie takie powodowało, że w sprawach o udzielenie koncesji na prowadzenie kasyna gry stosunkowo obniżony został poziom ochrony interesu publicznego względem standardu wyznaczonego przepisami ogólnymi regulującymi negatywne przesłanki przyznania koncesji.

Pomniejszenie na gruncie ustawy - Prawo przedsiębiorców katalogu negatywnych przesłanek ogólnych przyznania koncesji o te przesłanki obowiązujące w ustawie o swobodzie działalności gospodarczej, które nie znajdowały pełnego pokrycia w przesłankach otrzymania koncesji na prowadzenie kasyna gry (tj. przesłankę dotyczącą rękojmi prawidłowego wykonywania działalności gospodarczej oraz tzw. przesłankę temporalną z art. 61 u.s.d.g.) spowodowało, że poziom ochrony interesu publicznego w sprawach o udzielenie koncesji na prowadzenie kasyna gry w odniesieniu do ogólnego standardu ochrony zrównany został do poziomu ochrony występującego w sprawach o przyznanie pozostałych rodzajów koncesji. Zmianę tę należy ocenić pozytywnie, w ujęciu systemowym wyeliminowana została bowiem pewna niespójność w tym zakresie. Pomniejszenie ochrony interesu publicznego w sprawach o udzielenie koncesji na prowadzenie kasyna gry w sytuacji, gdy w sprawach o wydanie pozostałych rodzajów koncesji poziom tej ochrony był odpowiednio wyższy (wobec braku wyłączenia stosowania ogólnych negatywnych przesłanek przyznania koncesji), wydawało się niezrozumiałe i niepożądane. 


\section{Bibliografia}

Banaszak B., Konstytucja Rzeczypospolitej Polskiej. Komentarz, Legalis 2012.

Borkowski A. et al., Administracyjne prawo gospodarcze, Wrocław 2009.

Brożyna M. et al., Swoboda działalności gospodarczej. Komentarz, LEX/El. 2005.

Klecha K., Wolność działalności gospodarczej w Konstytucji RP, Warszawa 2009.

Kocowski T., Reglamentacja działalności gospodarczej w polskim administracyjnym prawie gospodarczym, Wrocław 2009.

Kohutek K., Komentarz do art. 50 u.s.d.g., [w:] M. Brożyna, M. Chudzik, K. Kohutek, J. Molis, S. Szuster, Swoboda działalności gospodarczej. Komentarz, LEX/El. 2005.

Kohutek K., Komentarz do art. 56 u.s.d.g., [w:] M. Brożyna, M. Chudzik, K. Kohutek, J. Molis, S. Szuster, Swoboda działalności gospodarczej. Komentarz, LEX/El. 2005.

Kosikowski C., Koncesje w prawie polskim, Kraków 1996.

Kosikowski C., Nowe regulacje prawne w zakresie swobody działalności gospodarczej, PiP 2004, z. 10.

Kosikowski C., Ustawa o swobodzie działalności gospodarczej. Komentarz, Warszawa 2013.

Szanciło T., Przedsiębiorca w prawie polskim, PPH 2005, nr 3.

Ustawa o swobodzie działalności gospodarczej. Komentarz, red. A. Powałowski, Warszawa 2009.

Waltoś S., Proces karny. Zarys systemu, Warszawa 2008.

Wołpiuk W., Sity zbrojne w regulacjach Konstytucji RP, Warszawa 1998.

Zdyb M., Komentarz do art. 46 u.s.d.g., [w:] M. Sieradzka, M. Zdyb, Ustawa o swobodzie działalności gospodarczej. Komentarz, Warszawa 2013.

\section{Orzeczenia}

Postanowienie SN z dnia 4 lipca 2012 roku, sygn. akt III SK 1/12, LEX nr 1238105.

Wyrok NSA z dnia 17 września 1997 roku, III SA 1425/96, LEX nr 32626.

Wyrok SN z dnia 8 maja 1998 roku, III RN 34/98, Legalis nr 42191.

Wyrok SA w Warszawie z dnia 12 grudnia 2007 roku, sygn. akt VI ACa 1019/07, LEX nr 1645903.

Uchwała 7 sędziów NSA z dnia 21 kwietnia 2008 roku, sygn. akt I OPS 2/08, LEX nr 364567.

Wyrok WSA w Warszawie z dnia 5 sierpnia 2010 roku, sygn. akt VI SA/Wa 1212/10, LEX nr 737911. Wyrok WSA w Warszawie z dnia 20 maja 2015 roku, sygn. akt VI SA/Wa 3504/14, LEX nr 2086071. Wyrok SA w Warszawie z dnia 23 czerwca 2015 roku, sygn. akt VI ACa 1123/14, LEX nr 1814847. Wyrok SN z dnia 9 lutego 2017 roku, sygn. akt III SK 71/15, LEX nr 2254781.

\section{Regulation of premises of granting a concession for operating casino games and the protection of the public interest}

\section{Summary}

Exclusion of application of general negative premises of granting a concession from the entrepreneurs law in cases of granting concession for operating casino games does not cause a limitation of protection of the public interest compared to standard which is appointed by general regulation. Premises of granting concession for operating casino games from the law on gambling do not have a narrower scope than general negative premises of granting a concession from the entrepreneurs law. Additionally, elimination a few general negative premises in the entrepreneurs law, which were applying in base of the repealed freedom of economic activity act, caused that level of the protection of public interest appointed by scope of general negative premises of granting a concession is not lower than level of the protection of public interest in cases of granting a concession for operating casino games. 